専門医症例報告

歯冠外型磁性アタッチメントを用いた補綴症例

中村 好德

\title{
A Case Report of a Prosthesis Using Extracoronal Magnetic Attachments
}

\author{
Yoshinori Nakamura
}

抄 録

症例の概要：患者は 60 歳男性。咀嚼・審美障害を主訴に来院した。上顎前歯部においては，歯根状態を 考慮し，レジン前装鋳造冠ブリッジとした。下顎については，残存前歯はすべてメタルボンドクラウンに て連結固定し，その遠心部に歯冠外型磁性アタッチメントを適用した部分床義歯を作製した.

考察：新義歯装着後，患者は審美的，機能的にも満足している. 現時点では術後経過には問題はないが, 審美性・機能性を追求したがゆえ複雑な設計の補綴物となった。今後，定期的なメインテナンスを行う必 要があると考える.

結論：歯冠外磁性アタッチメントを適応した部分床義歯を作製し，審美的，機能的にも良好な結果が得ら れた。

和文キーワード

磁性アタッチメント，歯冠外アタッチメント，歯冠外磁性アタッチメント

\section{ABSTRACT}

Patient: A 60-year-old male patient presented, and comprehensive dental treatment was rendered. Maxillary arch: A resin-bonded fixed partial denture was made for the upper anterior dentition, taking into consideration the periodontal status. Mandibular arch: The remaining mandibular anterior teeth were splinted with a fixed partial denture metal ceramic splint, having an extra-coronal attachment affixed to its distal aspects.

Discussion: The described prosthetic treatment was well accepted and tolerated by the patient, who expressed high satisfaction with the esthetic and functional results. A complicated design of the prosthesis was necessary to achieve satisfactory esthetic and functional results without use of conventional partial denture clasp retention designs. Frequent periodic observations and re-evaluations are necessary during the first year following treatment to ensure treatment success.

Conclusion: High esthetic and functional results of prosthetic restorative treatment were achieved with a partial denture that utilized extracoronal magnetic attachment retention.

\section{Key words}

magnetic attachment, extracoronal attachment, extracoronal magnetic attachment 


\section{I. 緒言}

近年，磁性アタッチメントは，歯科医療の一つの手段 として一般的にも広く認知され, 臨床現場において多様 に用いられるようになってきた。 その物理学的特徵から, 着脱方向の自由度が大きいため, 部分床義歯にクラスプ 等の他の維持装置と併用されることもしばしば見受けら れる。しかし, この場合, 義歯は磁性アタッチメントが 使用されているにもかかわらず，磁性アタッチメントの 特性を十分に生かすことか灘しくなる。特に高齢者におけ る義歯の着脱に関しては, クラスプ本来の種々の規制が 優位となり, 患者の満足も得られにくいことも事実である.

われわれは，磁性アタッチメントの開発当初から，ア タッチメントの価值を最大限に高めるには, 磁性アタッ チメントのみを利用した義歯が望ましいと考え，多様な 支台歯への適応範囲の拡大を目的として，有髄歯への利 用も検討してきた ${ }^{1-5)}$ 。今回，審美障害，咀嚼障害で来 院した患者に対し有髄歯にも利用可能な歯冠外磁性ア夕 ッチメントを用いた審美性，機能性を考慮した補綴処置 を行つたので報告する。

\section{II. 症例の概要}

患者: 60 歳, 男性.

初診: 平成 17 年 5 月 19 日.

主訴：義歯破折による咀嚼, 審美障害.

現病歴：平成 14 年に近在歯科医院にて, 上顎欠損部 には右側中切歯と左側側切歯を支台歯とした部分床義 歯, 下顎には, 両側犬歯遠心部に歯冠外アタッチメント を用いた部分床義歯が装着されていた。しかし, 装着後 約 2 年でアタッチメント部の破損のため, 近在の歯科 医院で治療を受けるが，審美的，機能的に満足が得られ ず当科を受診した。下顎臼歯部の欠損部は放置され，義 歯は使用していない状態であった。

現症：咬合接触状態は，右側では，上顎中切歯, 側切 歯と下顎側切歯, 犬歯である. 左側では上顎側切歯, 犬 歯と下顎側切歯, 犬歯, および上顎第一大臼歯と下顎第 二大臼歯の咬合接触である。前方のガイドについては, 上顎右側中切歯のみであり，側方ガイドは，右側につい ては, 側切歯, 犬歯であり, 左側については, 犬歯のみ である。下顎第二大鼠歯は動摇度が 3 度で, 歯周状態 も悪く保存不可と考えられる。また, 上顎前歯部の動摇, 不良補綴物, 歯肉の発赤・腫脹が認められた。左右上顎 第一小臼歯の欠損に対し遠心臼歯部からの延長ブリッジ が装着されていた。 a

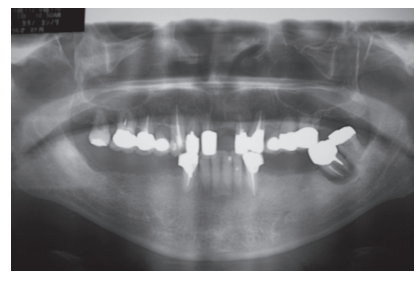

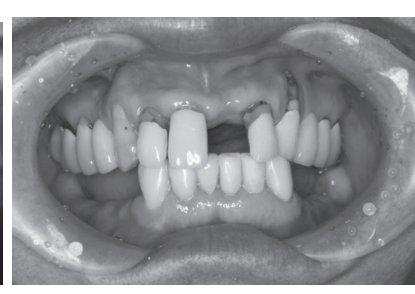

b
図 1 Intraoral view and orthopantomography at the examination a: orthopantomography, b: intraoral view 初診時口腔内写真およびパノラマX X 線 $\mathrm{a}$ : 口腔内写真, $b$ : パノラマX線

下顎は，当科初診時には，両側犬歯遠心部には，歯冠 外アタッチメントが装着されていたが，配当待機中に近 在歯科医院で除去され, 配当時には, 下顎前歯部にプロ ビジョナルレストレーションが装着されていた（図 1).

診断：下顎臼歯部欠損による咀嚼・審美障害, 上顎前 歯部欠損による審美障害.

治療方針：1. T.B.I. スケーリング・ルートプレーニ ング，2. 下顎左側 7 番の抜歯，3. 臼歯部の咬合支持 の獲得, 4. プロビジョナルレストレーションの装着, 5. 機能性・審美性を確認し最終補経物。

\section{III，治療内容と経過}

最初に, 上下顎前歯部にプロビジョナルレストレーシ ヨン，下顎欠損部に咬合支持を増すことを目的とした卜 リートメントデンチャーを装着した（図 2).

最終補経物の設計は，患者と相談のうえ，上顎前歯部 においては，歯根状態を考慮し，(3)(2) (1) 1 (2)(3)のレジ ン前装鋳造冠ブリッジとした。下顎については，クラス プが見えないようにして欲しいという患者の強い希望も あり, $\overline{3+3}$ をすべてメタルボンドクラウンにて連結 固定し, 左右犬歯遠心部に歯冠外型磁性アタッチメント を適用した部分床義歯を設計した。

下顎前歯部の支台歯形成が終了した口腔内写真を図 3 に，プロビジョナルレストレーションを装着した口腔内 を図 4 に示す。このプロビジョナルレストレーション にて, 咬合環境・歯周環境, 審美的要素を確立するとと もに，患者の要望も取り入れた形態に調整した。まず初 めに，下顎のプロビジョナルに対して，適正なアンテリ アガイドが得られるような上顎のレジン前装前装鋳造冠 ブリッジを作製した（図 5).

次に，各支台歯に通常の歯冠形態を付与したワックス パターンを作製し，それぞれの欠損側（本症例では 2 カ所 ) 舌側部にブレーシングアーム, インターロックの 形成を行い，この遠心部にサベイヤーを用いてそれぞれ 


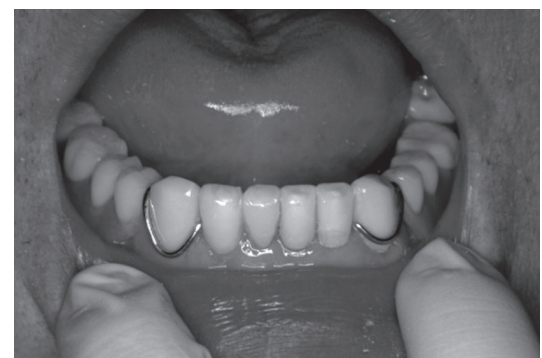

図 2 Intraoral view at treatment denture トリートメントデンチャー装着

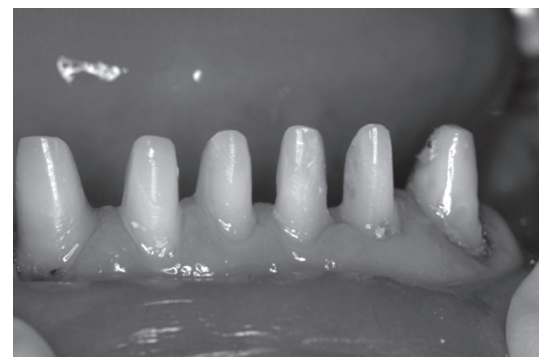

図 3 Preparation for abutment tooth of mandibular 下顎支台歯形成

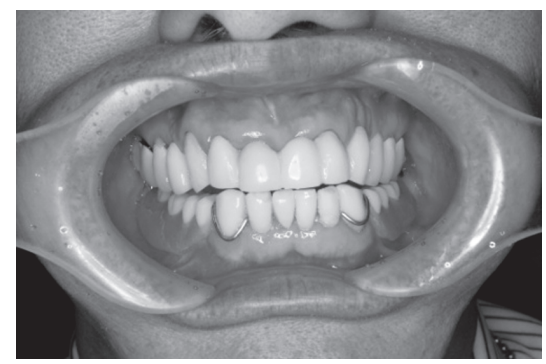

図 4 Intraoral views of inserting provisional restoration プロビジョナルレストレーション装着

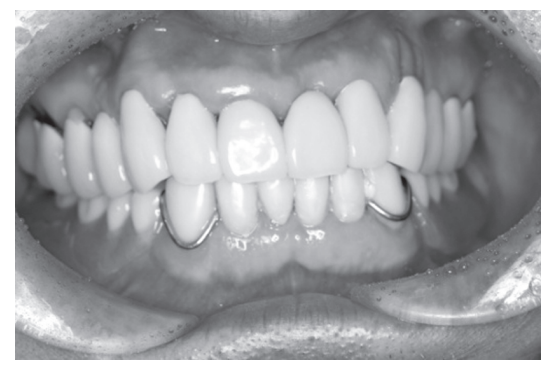

図 5 Intraoral view at maxillary final restorations 上㠝ファイナルレストレーション装着

ECキーパートレーを設置するが，これには通常のアタ ッチメント様ジグとして従来から市販されている，ユニ バーサルパラレルホルダー（ブレーデント社製，日本歯 科商社）を用いることで，作業の効率化をはかった（図 6)。鋳造後，前装部を完成した後，トランスファー印 象し，新たな作業用模型を作製した。フィメール部が完
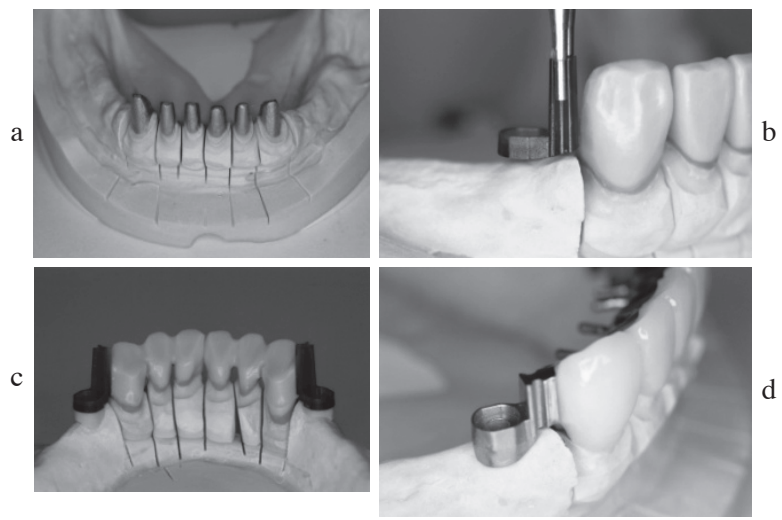

図 6 Manufacture of extracoronal magnetic attachment $\mathrm{a}$ : working cast, b: positioning of ready-made pattern, c: waxing up, d: mail of attachment 歯冠外磁性アタッチメントメール部の作製 $\mathrm{a}$ ：作業用模型，b：既成パターンの位置決め, $\mathrm{c} ：$ ワックスパターン, $\mathrm{d} ：$ メール部
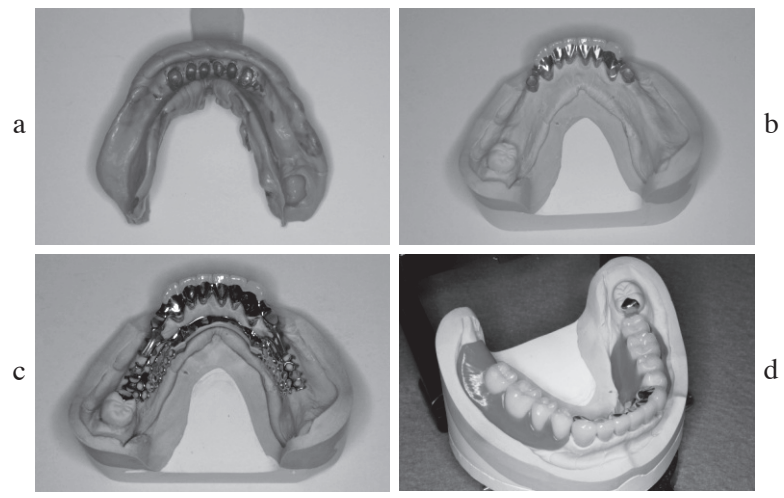

図 7 Manufacture of denture

a: transfer impression, b: working cast, c: framework, d: wax denture

義歯の作製

$\mathrm{a}$ ：トランスファー印象, b : 作業用模型, $\mathrm{c}:$ フレームワーク, $\mathrm{d}:$ 蝛義歯

成後, 通法通り義歯のメタルフレームを作製し蝉義歯を 完成した（図 7)。アタッチメント隣接部にはそれぞれ 舌側ブレーシングアームと近心縦溝が設定され（図 8), 完成義歯は口腔内で優れた審美性と磁性アタッチメント 義歯に特有のスムーズな着脱を具現した。最終補綴物の 咬合様式は, 前方運動時に臼歯部のディスクルージョン が得られるような適正なアンテリアガイダンスを設定し た。 側方運動時には，上顎前歯部の骨植状態を考慮して 犬歯, 第一, 二小臼歯のグループファンクションとした (図 9)。最終補綴装置装着後, 4 カ月ごとにメインテナ ンスを行なっている. 術後 4 年以上経過しているが, 特に大きな問題はなく, 歯冠外アタッチメント部の破損, 補経装置の脱離および歯周疾患への影響に対して注意深 く経過観察を行なっている(図 10). 


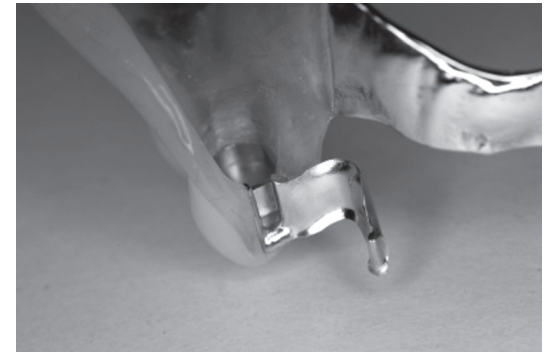

図 8 Bracing arm and interlock

ブレーシングアームとインターロック部

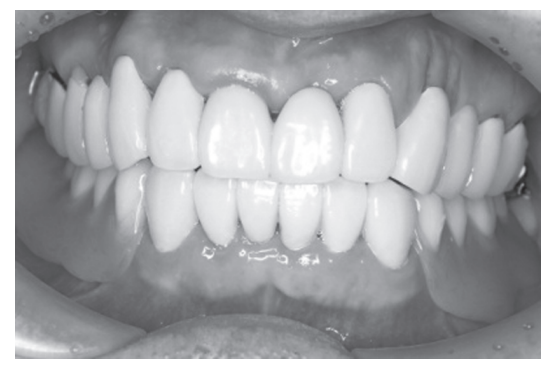

図 9 Intraoral view at final denture 完成義歯装着

\section{IV. 考 察}

新義歯装着後，患者は審美的，機能的にも満足してい る（図 10）。現時点では術後経過は良好であるが，審美 性・機能性を追求したがために, 複雑な設計の補綴物と なった。歯冠外型アタッチメントには臨床上本質的な問 題点として，アタッチメント部のカンチレバー作用や患 者自身のメインテナンスの困難さが挙げられる. しかし, 現時点では, 複数支台歯の連結固定によるカンチレバー 作用への対応，オーラルハイジーンの徹底指導による， 支台歯の安全確保や不潔域の克服などが可能であること を示しながら，有髄歯にも利用可能な磁性アタッチメン 卜を用いた部分床義歯の臨床的価值を強調したものであ る。現在の臨床で, 磁性アタッチメントの適用のみを理 由として，健全歯に便宜抜髄を施すことへの抵抗は小さ くないはずである，本システムの導入で，基本的にほと んぞの欠損症例に磁性アタッチメント義歯の適用が可能 となった意義は大きいものと考える。われわれの限られ た臨床経験ではあるが，歯冠外アタッチメント様式の磁 性アタッチメント義歯の術後経過は，現時点で全般的に きわめて良好である。

\section{V. 結 論}

磁性アタッチメントの研究や臨床活用が進むなか，臨

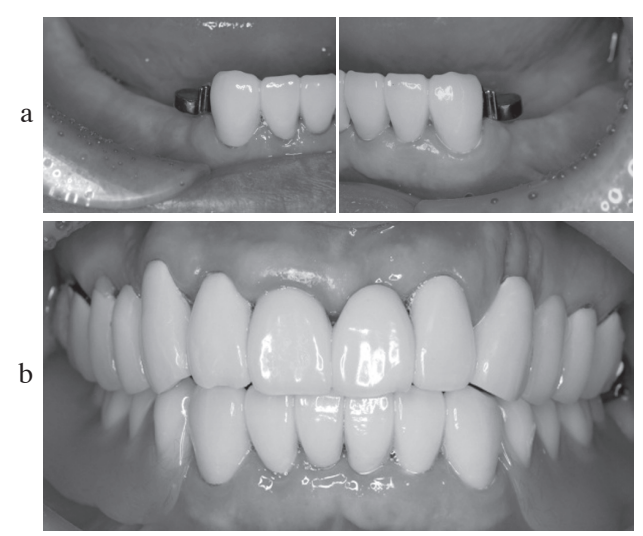

図 10 Intraoral view at four years after treatment a: extracoronal magnetic attachment, b: front view

治療終了後 4 年経過時の口腔内写真

$\mathrm{a}:$ 歯冠外アタッチメント, $\mathrm{b}$ : 正面観

床的な利用価值を高め適用範囲を広げる目的として開発 した歯冠外磁性アタッチメントの活用は，患者と術者双 方にとって有意義な結果をもたらすものと考えている. 臨床技法に関しては，本システムを利用することで，比 較的煩雑であった技工操作を簡略化し，義歯に必要な基 本形態を備えた臨床的価値の高い補綴物の製作がきわめ て容易となる，本症例に対して，歯冠外型磁性アタッチ メントシステムを適応することで，審美性，機能性を考 慮した補綴処置が行われた。

\section{文献}

1) Tanaka Y, Nakamura Y, Hoshiai K. General remarks concerning magnetic attachments in dentistry. Proc Japan Acad 2002; 78: 97-105.

2）中村好徳。磁性アタッチメントの新たな適応症一歯冠外 型磁性アタッチメントー. 愛院大歯誌 2008; 53: 21-28.

3) Ando A, Kumano H, Miyata T, Masuda T, Nakamura Y, Tanaka Y. The effect of tooth connection with a magnetic extracoronal attachment using the three dimensional Finite Element Method. J Jpn Magn Dent 2008; 17: 22-30.

4) Nakamura Y, Shoji K, Ando A, Tanaka T, Okada M, Imaoka $S$ et al. The full mouth reconstruction using magnetic attachments. J Jpn Magn Dent 2009; 18: 1-7.

5）中村好徳。有限要素法によるオーバーデンチャーと磁性 アタッチメントの力学的解析. 補綴誌 1998; 42: 234245.

著者連絡先：中村 好徳

干 464-8651 名古屋市千種区末盛通り 2-11

TEL: 052-759-2152

FAX: 052-759-2152

E-mail: nakamura@dpc.agu.ac.jp 